\title{
Effect of Hibiscus sabdariffa on Blood Glucose and Serum Electrolytes in Rats
}

\author{
LS Ojulari ${ }^{1}$, RO Oyeniyi ${ }^{1}$, BV Owoyele ${ }^{1}$ \\ ${ }^{1-}$ Department of Physiology, University of Ilorin, Nigeria.
}

\begin{abstract}
Hibiscus sabdariffa juice, commonly known as "zobo drink" is a type of beverage taken by many people due to its medicinal effect. HS is a medicinal plant which has been used for various purposes. This study was therefore, carried out to study the effect of oral administration of HS on blood glucose, serum sodium and serum potassium concentrations in albino rats. Twenty albino rats were divided into four groups of 5 rats each. Group A served as Control, while groups $B, C \& D$ were the experimental rats fed on aqueous extract of $H S$ orally at a $12 \mathrm{hr}$ interval, daily for 7, 14 and 21 days, respectively. The rats were sacrificed weekly by anaesthetizing them with chloroform and blood samples were collected through cardiac puncture. Blood samples were collected into fluoride oxalate bottles and plain bottles for blood glucose and serum electrolytes concentration analysis. The results showed a significant decrease $(P<0.05)$ in blood glucose level after 21 days of administration of HS and a significant decrease $(P<0.05)$ in serum sodium concentration at 7 and 14 days of administration. We concluded that HS has the capacity to decrease the blood glucose and serum sodium concentrations in a dose-dependent fashion.
\end{abstract}

Keywords: Hibiscus sabdariffa, blood glucose, sodium, potassium

\section{Introduction}

Hibiscus sabdariffa (HS) juice, commonly known as "zobo drink" is used as beverage by many people especially by people in south west Nigeria because of its medicinal values. HS is a medicinal plant which has been used for various purposes, such as in the treatment of hypertension ${ }^{[1]}$ and also in the treatment of diabetes ${ }^{[2]}$, and for some other purposes. HS is known in English as "red roselle" or "sorrel", and has been confirmed to be medicinal.

Blood glucose is maintained within a narrow limit in the body and the homeostasis is very important. Several factors have been reported to affect the level of blood glucose in the body ${ }^{[3]}$. Among these are dietary factors, hormonal and neural factors. A significant decrease (hypoglycemia) or increase (hyperglycemia) in the normal level of plasma glucose is detrimental to health and can lead to coma, among other complications.

Electrolytes in the body are important as well as the variable functions they perform in the maintenance of body osmolality, in the nerve impulse conduction and also some other functions in the body. The regulation of these electrolytes is also within a narrow range ${ }^{[4]}$.

HS appears to have limited evidence to support its effect on blood glucose and its control, but the evidence so far is in support. Mechanisms are not known, and the remarkable potency in animal studies seems to be markedly less in the limited human interventions looking at it ${ }^{[5]}$.

Correlations between blood glucose levels and serum electrolytes have been documented, but mostly in pathologic conditions ${ }^{[5]}$. Only a few studies have sought to determine the effect of HS on blood glucose levels and serum electrolyte in healthy conditions and also study the effect of this extract on the relationship between the two. This study aims to study the effect of HS on blood glucose and its effect on serum electrolytes.

\subsection{Preparation of extract}

\section{Materials And Methods}

$100 \mathrm{~g}$ of dry calyxes of HS was brewed in $400 \mathrm{ml}$ of boiling water. It was allowed to stand for $30 \mathrm{mins}$ and filtered. The decoction was placed in a water bath and was allowed to evaporate. It was then placed in the oven to dry. The residue was scrapped up and stored in glassware. The aqueous extract was prepared daily; $0.5 \mathrm{~g}$ was weighed and dissolved in $5 \mathrm{ml}$ of water. It was administered orally at a concentration of $100 \mathrm{ml} / \mathrm{kg}$ at $12 \mathrm{hrs}$ interval for seven, fourteen and twenty one days.

\subsection{Blood collection}

Experimental rats were sacrificed weekly by anaesthetizing them with chloroform and blood samples were collected using cardiac puncture. The blood samples were collected into fluoride oxalate bottles and plain bottles, as well, for blood glucose analysis and serum electrolyte concentration. 


\subsection{Blood glucose determination}

Blood glucose was measured by the glucose oxidase method (One Basic, Inc.). It involved the production of a coloured compound from the activities of glucose oxidase enzyme on Beta-D-glucose and the measurement of the coloured compound, colorimetrically.

\subsection{Serum electrolyte estimation}

Serum sodium and potassium analysis was carried out using the flame photometric method. The Jenway flame photometer was used. It involved use of the frequency of light lost by free atoms of an alkali metal salt to characterize the alkali metal.

\subsection{Statistical Analysis}

The mean values of the measured variables were determined and standard error of mean (SEM) was calculated. The test of significance was carried out using the Student's t-test. Differences in means were considered significant at $\mathrm{p}<0.05$.

\subsection{Effect of HS on blood glucose}

\section{Results}

Blood glucose levels in the control and experimental groups are shown in Table 1 below. Blood glucose was $4.5 \pm 0.21 \mathrm{mmol} / \mathrm{L}$ in the control group compared to $3.93 \pm 0.41 \mathrm{mmol} / \mathrm{L}, 3.83 \pm 0.64 \mathrm{mmol} / \mathrm{L}$ and $3.28 \pm 0.38 \mathrm{mmol} / \mathrm{L}(\mathrm{p}<0.05)$, in group B (7 days administration of HS), C (14 days administration of HS) and D (21 days administration of HS), respectively. Only the observed decrease in group D was significant $(p<0.05)$ when compared to control.

\subsection{Effect of HS on Sodium ion concentration}

Sodium ion concentration was $164.5 \pm 2.06 \mathrm{mmol} / \mathrm{L}$ in the control, while the values were $152 \pm 2.95$ $\mathrm{mmol} / \mathrm{L}(\mathrm{p}<0.05)$ in group $\mathrm{B}, 155 \pm 2.65 \mathrm{mmol} / \mathrm{L}(\mathrm{p}<0.05)$ in group $\mathrm{C}$ and $161 \pm 1.00 \mathrm{mmol} / \mathrm{L}$ in group $\mathrm{D}$. Observed changes were significant $(\mathrm{p}<0.05)$ in groups $\mathrm{B}$ and $\mathrm{C}$ when compared control but insignificant $(\mathrm{P}>0.05)$ in group D. This is also shown in the Table 1 below.

\subsection{Effect of HS on potassium ion concentration}

The effect of HS on serum potassium ion concentration is shown in the table 1 below. The results show that the observed changes in the experimental groups when compared to the control group were not significant $(\mathrm{p}>0.05)$.

\section{Table}

Table 1: Effect of oral administration of Hibiscus sabdariffa on blood glucose, serum sodium and serum potassium concentration in rats

\begin{tabular}{|c|c|c|c|c|}
\hline $\begin{array}{l}\text { Groups } \\
\text { Parameters }\end{array}$ & $\begin{array}{l}\text { A (Control) } \\
\text { Distilled water }\end{array}$ & $\begin{array}{l}\text { B (7d administration } \\
\text { of HS) }\end{array}$ & $\begin{array}{l}\mathrm{C}(14 \mathrm{~d} \\
\text { administration of } \\
\text { HS })\end{array}$ & $\begin{array}{l}\mathrm{D}(21 \mathrm{~d} \\
\text { administration of } \\
\text { HS) }\end{array}$ \\
\hline Serum $\mathrm{Na}^{+}(\mathrm{mMol} / \mathrm{L})$ & $164 \pm 2.06$ & $152 \pm 2.95^{*}$ & $155 \pm 2.65^{*}$ & $161 \pm 1.00$ \\
\hline Serum K ${ }^{+}(\mathrm{mMol} / \mathrm{L})$ & $11.9 \pm 1.60$ & $11.3 \pm 1.46$ & $10.9 \pm 1.38$ & $11.3 \pm 1.87$ \\
\hline $\begin{array}{l}\text { Plasma Glucose } \\
(\mathrm{mMol} / \mathrm{L})\end{array}$ & $4.5 \pm 0.21$ & $3.9 \pm 0.41$ & $3.83 \pm 0.64$ & $3.28 \pm 0.38^{*}$ \\
\hline
\end{tabular}

\section{Discussion}

The present study demonstrated the effect of HS extract on blood glucose and serum electrolytes concentration. HS components includes organic acids, flavonoids, polysaccharides ${ }^{[6]}$, which is suggested to be responsible for most of its pharmacologic activities ${ }^{[7]}$

The results show that oral administration of the aqueous extract of HS in rats produced a significant change $(\mathrm{p}<0.05)$ on fasting blood glucose after 21 days. This finding corresponds with studies by Ajagbonna \& Adebayo (1999) ${ }^{[2]}$ who reported that HS extract reduces blood glucose level. It has also been shown that HS appears to inhibit the alpha-glucosidase enzyme ${ }^{[8]}$. This enzyme breaks down starch and disaccharides to glucose by acting on the 1, 4-alpha bonds. Inhibition of this enzyme would cause a subsequent decrease in blood glucose levels

Oral administration of HS in rats for 7 and 14 days, respectively, caused a significant decrease $(\mathrm{p}<0.05)$ in the concentration of serum sodium. This corresponds with findings by Al-Rubean et al (2011) ${ }^{[9]}$ and Bukonla et al (2012) ${ }^{[10]}$ who recorded a significant reduction in serum sodium levels after oral administration of HS, but 
this was in Type 1 diabetic patients. Though Ajagbonna \& Adebayo (1999) ${ }^{[2]}$ and Onyenekwe et al (1997) ${ }^{[11]}$, reported that HS had no significant effect on serum sodium concentration.

Several studies have tried to show the correlation between blood glucose and serum sodium levels ${ }^{[5,9]}$, but mostly in pathologic conditions. While Yurdakok (1992) ${ }^{[5]}$ showed a positive correlation between blood glucose and serum sodium in cases of metabolic acidosis, Al-Rubeaan $(2011)^{[9]}$ reported a significant reduction in serum sodium level in Type 1 and Type 2 diabetics, especially amongst insulin-treated patients.

\section{Conclusion}

This study showed that HS may have significant effects on the blood glucose level and serum sodium concentration in a dose-dependent fashion. HS has been shown to be effective in reducing blood pressure, have anti-fertility effects in men and alter serum sodium levels in some pathologic conditions. It would be of great scientific interest to study its effect on the seemingly positive correlation between serum glucose and serum electrolytes in healthy and pathologic conditions.

\section{References}

[1]. B.Y. Adegunloye, J.O. Omoniyi, O.A. Owolabi, O.P. Ajagbona, O.A. Sofola, H.A. Coker, Mechanisms of the blood pressure lowering effect of Calyx extract of Hibiscus sabdariffa in rats, African Journal of Medical Science, 25(3), 1996, 235-38

[2]. O.P. Ajagbona and A.A. Adebayo, Blood glucose lowering effect of Hibiscus sabdariffa in albino rats, Nigerian Journal of Physiological Science, 15, 1999, 1-2

[3]. P.A. Jackson, C. Sylvian, S.C. Christopher, N. Dossin, Effect of the hepatic denervation on the conterregulatory response to insulininduced hyperglycemia in drugs, American Journal of Physiology, Endocrinology and Metabolism, 279, 2000, E1249-E1257

[4]. F.O. Agoreyo, B.O. Agoreyo, M.I. Onuorah, Effect of aqueous extracts of Hibiscus sabdariffa and Zingiber officinale on blood cholesterol and glucose levels in rats, Afr J of Biotech, 7(21), 2008, 3949-51

[5]. K. Yurdakok and O. Oran, The relationship between blood glucose and serum electrolyte levels in children with acute diarrhea, Turkish Journal of Pediatrics, 34(3), 1992, 145-52

[6]. B.M. Muller, and G. Franz, Clinical structure and biological activity of polysaccharides form Hibiscus sabdariffa, Planta Medica, 58(1), 1992, 607

[7]. A.A. Daffalah and Z. Al-Mustapha, Investigation of the anti-inflammatory effect of Acacia nicotica and Hibiscus sabdariffa, American Journal of Clinical Medicine, 24(34), 1996, 263-69

[8]. A.O. Ademiluyi, G. Oboh, Aqueous extract of Roselle varieties inhibit $\alpha$-amylase and glucosidase activities in-vitro, Journal of Medicinal Food, 16(11), 2012, 86-93

[9]. K. Al-Rubean, K. Siddiqui, A.A. Abu-Rishihk, Correlation between serum electrolyte and fasting glucose Hb 1 Ac in Saudi diabetic patients, Biological Trace Element Research, 144(1-3), 2011, 463-6

[10]. A. Bukonla, O.K. Benson, A.R. Akinola, C. Arigbola, A. Adesola, A. Seyi, A, Effects of Type 1 Diabetes on serum electrolyte (sodium \& potassium) levels and testosterone hormones in human male subjects, Webmed Central, Biochemistry; 3(9), 2012, WMCOO 3698

[11]. P.C. Oyenekwe, E.O. Ajani, D.A. Ameh, K.S. Gamamiel, Antihypertensive effect of roselle (Hibiscus sabdariffa) calyx, infusion spontaneously hypertensive rat and comparison of its toxicity on Wistar rats, Cell Biochemistry and Function, 17(3), 1999, 199-206 